\title{
Some insights into the condensing vapors driving new particle growth to CCN sizes on the basis of hygroscopicity measurements
}

\author{
Z. J. Wu ${ }^{1,2}$, L. Poulain ${ }^{2}$, W. Birmili ${ }^{2}$, J. Größ ${ }^{2}$, N. Niedermeier ${ }^{2}$, Z. B. Wang ${ }^{3}$, H. Herrmann ${ }^{2}$, and A. Wiedensohler ${ }^{2}$ \\ ${ }^{1}$ State Key Joint Laboratory of Environmental Simulation and Pollution Control, College of Environmental Sciences and \\ Engineering, Peking University, Beijing 100871, China \\ ${ }^{2}$ Leibniz Institute for Tropospheric Research, 04318 Leipzig, Germany \\ ${ }^{3}$ Multiphase Chemistry Department, Max Planck Institute for Chemistry, 55128 Mainz, Germany
}

Correspondence to: Z. J. Wu (zhijunwu@pku.edu.cn)

Received: 6 March 2015 - Published in Atmos. Chem. Phys. Discuss.: 20 March 2015

Revised: 28 October 2015 - Accepted: 28 October 2015 - Published: 25 November 2015

\begin{abstract}
New particle formation (NPF) and growth is an important source of cloud condensation nuclei (CCN). In this study, we investigated the chemical species driving new particle growth to the $\mathrm{CCN}$ sizes on the basis of particle hygroscopicity measurements carried out at the research station Melpitz, Germany. Three consecutive NPF events occurred during summertime were chosen as examples to perform the study. Hygroscopicity measurements showed that the $\left(\mathrm{NH}_{4}\right)_{2} \mathrm{SO}_{4}$-equivalent water-soluble fraction accounts for 20 and $16 \%$ of 50 and $75 \mathrm{~nm}$ particles, respectively, during the NPF events. Numerical analysis showed that the ratios of $\mathrm{H}_{2} \mathrm{SO}_{4}$ condensational growth to the observed particle growth were 20 and $13 \%$ for 50 and $75 \mathrm{~nm}$ newly formed particles, respectively. Aerosol mass spectrometer measurements showed that an enhanced mass fraction of sulfate and ammonium in the newly formed particles was observed when new particles grew to the sizes larger than $30 \mathrm{~nm}$ shortly after the particle formation period. At a later time, the secondary organic species played a key role in the particle growth. Both hygroscopicity and aerosol mass spectrometer (AMS) measurements and numerical analysis confirmed that organic compounds were major contributors driving particle growth to CCN sizes. The critical diameters at different supersaturations estimated using AMS data and $\kappa$-Köhler theory increased significantly during the later course of NPF events. This indicated that the enhanced organic mass fraction caused a reduction in CCN efficiency of newly formed particles. Our results implied that the CCN production associated with atmospheric nucleation may be overestimated if assuming that newly formed particles can serve as $\mathrm{CCN}$
\end{abstract}

once they grow to a fixed particle size, an assumption made in some previous studies, especially for organic-rich environments. In our study, the enhancement in $\mathrm{CCN}$ number concentration associated with individual NPF events were 63, 66 , and $69 \%$ for $0.1,0.4$, and $0.6 \%$ supersaturation, respectively.

\section{Introduction}

The formation of new particles from gaseous precursors and their subsequent growth represent a key stage in the life cycle of atmospheric aerosol particles. This new particle formation (NPF) process represents an important source of atmospheric particles and possibly also for the number concentration of cloud condensation nuclei (CCN) (Spracklen et al., 2008; Wiedensohler et al., 2009; Wang and Penner, 2009; Laaksonen et al., 2005; Yue et al., 2011; Kazil et al., 2010; Sotiropoulou et al., 2006; Laakso et al., 2013). NPF thus has the potential to influence climatologically important processes such as precipitation patterns and Earth's energy balance (Paasonen et al., 2013). The contribution of atmospheric nucleation to the global CCN budget spans a relatively large uncertainty range, which, together with our general poor understanding of aerosol-cloud interactions, results in major uncertainties in the radiative forcing by atmospheric aerosols (Kerminen et al., 2012). Recent model studies (Spracklen et al., 2008; Merikanto et al., 2009; Westervelt et al., 2014) have attempted to elaborate on the connection between NPF and 
$\mathrm{CCN}$ production, a process that is sensitive to a number of environmental factors.

Freshly formed particles are about $1 \mathrm{~nm}$ in diameter (Kulmala et al., 2012), and they must grow tens of nanometers in order to serve as a CCN (Dusek et al., 2006; Kerminen et al., 2012). Apparently, the nucleation rate, the particle growth, and the rate at which growing particles are removed by coagulation or deposition greatly influence the $\mathrm{CCN}$ production associated with atmospheric nucleation (Kuang et al., 2009; Kerminen et al., 2004). With regard to chemical species, both sulfuric acid and organics contribute to the subsequent particle growth after nucleation (Smith et al., 2004; Pierce et al., 2011; Ehn et al., 2007; Kulmala et al., 2004, 2006; Brus et al., 2011; Sipilä et al., 2010; R. Zhang et al., 2004; Kiendler-Scharr et al., 2009; Wang et al., 2010; Ristovski et al., 2010). The contribution of sulfate and organics in the particle growth seems to be strongly dependent on the location (e.g., Yue et al., 2010; Boy et al., 2005). For example, sulfuric acid fully explains the particle growth observed in the polluted urban areas of Atlanta, USA (Stolzenburg et al., 2005), while it represents only $10 \%$ in boreal forest area (Boy et al., 2005).

Due to the differences in hygroscopicity of sulfuric acid and/or its ammonium salts and secondary organic compounds (Virkkula et al., 1999; Varutbangkul et al., 2006; Tang and Munkelwitz, 1994), hygroscopicity measurements during a NPF event can provide insight into the changes in condensing vapor properties and chemical composition of newly formed particles (Hämeri et al., 2001; Ehn et al., 2007; Ristovski et al., 2010). In this study, we investigated the chemical species driving new particle growth into $\mathrm{CCN}$ sizes by using experimental data on particle hygroscopicity and chemical composition measured at Melpitz, Germany. In addition, the production of potential $\mathrm{CCN}$ associated with the NPF event was evaluated.

\section{Measurements}

Atmospheric measurements were performed at the research station Melpitz, Germany $\left(51.54^{\circ} \mathrm{N}, 12.93^{\circ} \mathrm{E} ; 86 \mathrm{~m}\right.$ above sea level). The atmospheric aerosol observed at Melpitz can be regarded as representative for central European background conditions (Birmili et al., 2009). An account of the NPF process at Melpitz and its relationship with precursor gases and meteorology can be found in Größ et al. (2015).

The data of this study were collected during the European Integrated Project on Aerosol Cloud Climate Air Quality Interactions (EUCAARI; Kulmala et al., 2009) intensive field campaign from 23 May to 8 June in 2008. Table 1 summarizes the instruments and measured parameters used in this study. All instruments were set up in the same container laboratory and utilized the same air inlet. The inlet line consisted of a $\mathrm{PM}_{10}$ Anderson impactor located approximately $6 \mathrm{~m}$ above ground level and directly followed by an automatic aerosol diffusion dryer (Tuch et al., 2009) that maintained the relative humidity in the sampling line below $30 \%$. Particle hygroscopicity, particle number size distribution, and chemical composition of non-refractory $\mathrm{PM}_{1}$ were determined using a hygroscopicity tandem differential mobility particle analyzer (H-TDMA), a twin differential mobility particle sizer (TDMPS), and a high-resolution time-of-flight aerosol mass spectrometer (HR-ToF-AMS), respectively.

\subsection{Particle hygroscopicity measurements}

The H-TDMA used in this study has been described in previous publications in detail (Wu et al., 2011; Maßling et al., 2003) and complies with the instrumental standards prescribed in Massling et al. (2011). The H-TDMA consists of three main parts: (1) a differential mobility analyzer (DMA1) that selects quasi-monodisperse particles at a relative humidity below $10 \%$ and a condensation particle counter (CPC1) that measures the particle number concentration leaving DMA1 at the selected particle size, (2) an aerosol humidifier conditioning the particles selected by DMA1 to a defined relative humidity ( $\mathrm{RH}$ ), and (3) a second DMA (DMA2) coupled with another condensation particle counter (CPC2) to measure the number size distributions of the humidified aerosol. DMA2 and the aerosol humidification are placed in a temperature-controlled box. Hygroscopicity scans with $100 \mathrm{~nm}$ ammonium sulfate particles were performed frequently to analyze the stability of the relative humidity of $90 \%$ in the second DMA. Hygroscopicity measurements with RH between 87 and $90 \%$ were accepted for further analysis.

The hygroscopic growth factor (HGF) is defined as the ratio of the particle mobility diameter, $D_{\mathrm{p}}(\mathrm{RH})$, at a given $\mathrm{RH}$ to the dry diameter, $D_{\mathrm{p}_{\mathrm{dry}}}$ :

$\operatorname{HGF}(\mathrm{RH})=\frac{D_{\mathrm{p}}(\mathrm{RH})}{D_{\mathrm{pdry}}}$.

The TDMAinv method developed by Gysel et al. (2009) was used to invert the H-TDMA data. Dry scans $(\mathrm{RH}<10 \%)$ were used to calibrate a possible offset between DMA1 and DMA2 and define the width of the H-TDMA's transfer function (Gysel et al., 2009). In this study, the particles with dry sizes of $35,50,75,110,165$, and $265 \mathrm{~nm}$ were measured by $\mathrm{H}$-TDMA at $\mathrm{RH}=90 \%$ with a time resolution of $1 \mathrm{~h}$. The HGFs of 35, 50, and $75 \mathrm{~nm}$ particles will be taken for further analysis.

The hygroscopicity parameter, $\kappa$, can be calculated from the HGF measured by H-TDMA (Petters and Kreidenweis, 2007): 
Table 1. Summary of instruments and parameters used in this study.

\begin{tabular}{ll}
\hline Instrument & Parameter \\
\hline TDMPS & Particle number size distribution \\
H-TDMA & Particle hygroscopicity \\
HR-ToF-AMS & Size-resolved chemical composition \\
Monitor - APSA 360 Horiba Europe & $\mathrm{SO}_{2}$ concentration \\
Kipp \& Zonen CM6 pyranometer & Global solar irradiance \\
\hline
\end{tabular}

$\kappa_{\mathrm{HTDMA}}=\left(\mathrm{HGF}^{3}-1\right)\left(\frac{\exp \left(\frac{A}{D_{\mathrm{P}_{\mathrm{dry}}} \cdot \mathrm{HGF}}\right)}{\mathrm{RH}}-1\right)$,

$A=\frac{4 \sigma_{\mathrm{s} / \mathrm{a}} M_{\mathrm{w}}}{\mathrm{RT} \rho_{\mathrm{w}}}$

where $D_{\mathrm{p}_{\mathrm{dry}}}$ and HGF are the initial dry particle diameter and the hygroscopic growth factor at $90 \% \mathrm{RH}$ measured by $\mathrm{H}-$ TDMA, respectively. $\sigma_{\mathrm{s} / \mathrm{a}}$ is the droplet surface tension (assumed to be that of pure water, $\sigma_{\mathrm{s} / \mathrm{a}}=0.0728 \mathrm{~N} \mathrm{~m}^{-2}$ ), $M_{\mathrm{W}}$ the molecular weight of water, $\rho_{\mathrm{W}}$ the density of liquid water, $R$ the universal gas constant, and $T$ the absolute temperature.

\subsection{Particle chemical composition}

The Aerodyne HR-ToF-AMS (here simply referred to as AMS) (DeCarlo et al., 2006) was operated with a time resolution of $5 \mathrm{~min}$. Due to the $600^{\circ} \mathrm{C}$ surface temperature of the vaporizer, the AMS only analyzes the non-refractory chemical composition of the particles. Soot, crustal material, and sea salt cannot be detected. The aerodynamic lenses have $100 \%$ transmission efficiency down to $70 \mathrm{~nm}$ in a vacuum aerodynamic diameter (Canagaratna et al., 2007). Therefore, based on the transmission efficiency of the aerodynamic lenses and the detected compounds, the AMS can provide the size-resolved chemical composition of submicrometer nonrefractory aerosol particle fraction (NR-PM1) (Canagaratna et al., 2007). The vacuum aerodynamic diameter for AMS measurements was converted to mobility diameter by division of AMS vacuum aerodynamic diameter by the estimated particle density $\left(1400 \mathrm{~kg} \mathrm{~m}^{-3}\right)$. Hereafter, the mobility diameter is used in AMS data below. The particle density was calculated on the basis of measured chemical composition. The detail description can be found in Poulain et al. (2014).

\subsection{Particle number size distribution}

A TDMPS was deployed to measure particle number size distributions from 3-800 nm mobility diameter with a time resolution of 10 min (Birmili et al., 1999). The system consists of two differential mobility analyzers (DMAs, Hauke type) and two condensation particle counters (CPCs, TSI

model 3010 and TSI model 3025). The sheath air is circulated in closed loops for both DMAs. Evaluation of particle number size distributions includes a multiple-charge inversion, and the CPC counting efficiency and diffusional loss corrections in the DMA and all internal and external sampling lines according to the recommendations in Wiedensohler et al. (2012).

\section{Methodology}

\subsection{Derivation of the soluble particle fraction}

Based on the Zdanovskii-Stokes-Robinson (ZSR) method (Stokes and Robinson, 1966; Zdanovskii, 1948), the HGF of a mixture can be estimated from the sum of $\mathrm{HGF}_{i}$ of a pure component $(i)$ multiplied by their respective volume fractions, $\varepsilon_{i}$ (Malm and Kreidenweis, 1997):

$\mathrm{HGF}_{\text {mixed }}=\left(\sum_{i} \varepsilon_{i} \mathrm{HGF}_{i}^{3}\right)^{1 / 3}$.

Here, the chemical compounds contributing to the particle growth are separated into two fractions, i.e., soluble and insoluble fractions (also refer to Ehn et al., 2007; Swietlicki et al., 1999). The soluble fraction is assumed to be ammonium sulfate and the insoluble fraction to be organic compounds. Then, $\varepsilon$ of soluble fraction can be calculated by

$\varepsilon_{\text {soluble }}=\frac{\mathrm{HGF}_{\text {measured }}^{3}-1}{\mathrm{HGF}_{\left(\mathrm{NH}_{4}\right)_{2} \mathrm{SO}_{4}}^{3}-1}$,

where $\mathrm{HGF}_{\text {measured }}$ is the $\mathrm{HGF}$ of particle measured by $\mathrm{H}$ -

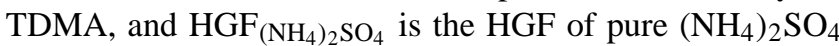
particle with the same size. When calculating $\mathrm{HGF}\left(\mathrm{NH}_{4}\right)_{2} \mathrm{SO}_{4}$ in different diameters, the parameterizations for $\left(\mathrm{NH}_{4}\right)_{2} \mathrm{SO}_{4}$ water activity developed by Potukuchi and Wexler (1995) and the density reported by Tang and Munkelwitz (1994) are used. The Kelvin term was considered in the calculation.

The assumption of an insoluble organic fraction may lead to overestimation of the soluble fraction because atmospherically relevant secondary organics typically have a growth factor larger than 1 (e.g., Varutbangkul et al., 2006). This implies that, in the presence of several classes of hygroscopic substances, $\varepsilon$ derived from Eq. (5) is only an "equivalent" 
soluble fraction (i.e., assuming ammonium sulfate as the only soluble substance). $\varepsilon_{\text {soluble }}$ is therefore an upper estimate for the true soluble volume fraction. The advantage of using the equivalent water-soluble fraction term is to be able to analyze the particle hygroscopicity independently of differences in size. The uncertainty of the estimated soluble volume fraction is around $5 \%$, which was derived from the measurement uncertainty of HGF $(2.5 \%)$ according to the error propagation function.

\subsection{Calculation of $\mathrm{CCN}$ number concentration}

The CCN number concentration can be estimated by integrating the particle number size distribution from the critical diameter to the maximum diameter detected by TDMPS ( $800 \mathrm{~nm}$, above which the particle number concentration is generally negligible), assuming particles are internal mixture. The critical diameter $\left(D_{\mathrm{p}_{\text {crit }}}\right)$ is calculated from $\kappa$ :

$D_{\text {prit }_{\text {crit }}}=\left(\frac{4 A^{3}}{27 \kappa_{\text {chem }} \ln ^{2} S_{\mathrm{C}}}\right)^{1 / 3}$.

Here, $D_{\mathrm{p}_{\text {crit }}}$ is the critical diameter at which $50 \%$ of the particles were activated at the supersaturation, $S_{\mathrm{C}}(0.1,0.4$, and $0.6 \%$ were chosen in this study). $\kappa_{\text {chem }}$ is calculated from size-resolved AMS data according to the ZSR method and $\kappa$-Köhler theory (Petters and Kreidenweis, 2007):

$\kappa_{\mathrm{chem}}=\sum_{i} \varepsilon_{i} \kappa_{i}$

Here, $\kappa_{i}$ and $\varepsilon_{i}$ are the hygroscopicity parameter and volume fraction for the individual (dry) component in the mixture, with $i$ the number of components in the mixture. The volume fraction of each chemical species in the mixture was derived from the size-resolved AMS data as described below.

Particle mass size distributions of organics, sulfate $\left(\mathrm{SO}_{4}^{2-}\right)$, nitrate $\left(\mathrm{NO}_{3}^{-}\right)$, and ammonium $\left(\mathrm{NH}_{4}^{+}\right)$ions were detected by AMS. We use a simplified ion-pairing scheme as presented in Gysel et al. (2007) to convert the ion mass concentrations to the mass concentrations of their corresponding inorganic salts as listed in Table 2. The critical diameters, corresponding to supersaturation (SS) of $0.2-0.6 \%$, roughly spanned from 50 to $120 \mathrm{~nm}$ in mobility diameter. Therefore, by integrating the particle mass size distribution from 50 to $120 \mathrm{~nm}$, the mass concentrations of organics, $\mathrm{SO}_{4}^{2-}, \mathrm{NO}_{3}^{-}$, and $\mathrm{NH}_{4}^{+}$ions were calculated to estimate $\kappa_{\text {chem. }}$. In the same way, the chemical composition of $150-200 \mathrm{~nm}$ particles is used to calculate $\kappa_{\text {chem }}$ for the critical diameter of around $170 \mathrm{~nm}$, which corresponds to a supersaturation of $0.1 \%$.

The H-TDMA-derived $\kappa$ was not used in calculating the critical diameter. This was due to inconsistencies between H-TDMA-derived $\kappa$ and cloud condensation nuclei counter $(\mathrm{CCNc})$-derived $\kappa$ having been reported in several previous studies (Good et al., 2010; Cerully et al., 2011; Irwin et al., 2010; Petters et al., 2009; Wex et al., 2009). Possible expla- nations are non-ideality effects in the solution droplet, surface tension reduction due to surface active substances, and the presence of slightly soluble substances which dissolve at RHs larger than the one considered in the H-TDMA (Wex et al., 2009). Due to these effects, $\kappa$ is not necessarily constant and may vary with humidity. Extrapolating from H-TDMA data to properties at the point of activation should be done with great care (Wu et al., 2013). In addition, our previous study (Wu et al., 2013) showed that critical diameters at different supersaturations can be well predicted using AMS data and the ZSR method. Therefore, it was decided that the AMS data would be used to estimate the critical diameters instead of H-TDMA-derived $\kappa$.

\subsection{Estimation of $\mathrm{H}_{2} \mathrm{SO}_{4}$ concentration}

$\mathrm{H}_{2} \mathrm{SO}_{4}$ concentrations were estimated using a modified version of the chemical mass balance model introduced by Weber et al. (1997), driven by solar radiation as a source of $\mathrm{OH}$ :

$\left[\mathrm{H}_{2} \mathrm{SO}_{4}\right]=B \frac{[\cdot \mathrm{OH}]\left[\mathrm{SO}_{2}\right]}{\mathrm{CS}}\left[\mathrm{cm}^{-3}\right]$.

Here, $[\cdot \mathrm{OH}]$ is the hydroxyl radical concentration estimated from Eq. (9) in $\mathrm{cm}^{-3}$. $\left[\mathrm{SO}_{2}\right]$ is the measured sulfur dioxide concentration in $\mathrm{cm}^{-3} . B$ is a constant related to the reaction rate of the two species. CS is the condensation sink (Pirjola et al., 1999) in $\mathrm{s}^{-1}$ calculated from the particle number size distribution adjusted to ambient relative humidity. For this adjustment, an empirical growth law based on 1 year of hygroscopicity measurements at Melpitz was used (refer to Laakso et al., 2004). The term $B[\cdot \mathrm{OH}]\left[\mathrm{SO}_{2}\right]$ represents the production term of $\mathrm{H}_{2} \mathrm{SO}_{4}$, and CS refers to represent the loss rate of $\mathrm{H}_{2} \mathrm{SO}_{4}$ on the preexisting particles. $B$ was derived by correlation analysis of measured and estimated $\left[\mathrm{H}_{2} \mathrm{SO}_{4}\right]$ for 9 days during EUCAARI-2008 for which the data capture was satisfactory. Linear regression analysis yielded a value of $27.49 \times 10^{-13} \mathrm{~cm}^{3} \mathrm{~s}^{-1}$ for $B$.

$[\cdot \mathrm{OH}]=A^{\prime} \cdot \operatorname{Rad}\left[\mathrm{cm}^{-3}\right]$

where $\mathrm{Rad}$ is the global solar radiation flux in $\mathrm{W} \mathrm{m}^{-2} \cdot A^{\prime}$ was derived by linear regression of these parameters for the EUCAARI-2008 data set, yielding a value of $6166 \mathrm{~m}^{2} \mathrm{~W}^{-1}$ for $A^{\prime}$. The calculation of $\mathrm{H}_{2} \mathrm{SO}_{4}$ concentration was done in Größ et al. (2015); details can be found therein. The accuracy of simulated $\mathrm{H}_{2} \mathrm{SO}_{4}$ concentration is estimated as follows: percentage error $=\mathrm{abs}\left(\left[\mathrm{H}_{2} \mathrm{SO}_{4}\right]_{\text {measured }}-\left[\mathrm{H}_{2} \mathrm{SO}_{4}\right]_{\text {simulated }}\right)$ . $100 /\left[\mathrm{H}_{2} \mathrm{SO}_{4}\right]_{\text {simulated }}$. Here, $\left[\mathrm{H}_{2} \mathrm{SO}_{4}\right]_{\text {measured }}$ is the sulfuric acid concentration measured during 9-day measurements for EUCAARI-2008. The percentage error is around $40 \%$.

\subsection{Calculation of particle formation and growth rate}

Assuming a constant particle source during a time period of $t$, the particle formation rate $\left(J_{\text {nuc }}\right)$ can be expressed as (Dal 
Table 2. Gravimetric densities $\rho$ and hygroscopicity parameters $\kappa$.

\begin{tabular}{lrrrrr}
\hline Species & $\mathrm{NH}_{4} \mathrm{NO}_{3}$ & $\mathrm{H}_{2} \mathrm{SO}_{4}$ & $\mathrm{NH}_{4} \mathrm{HSO}_{4}$ & $\left(\mathrm{NH}_{4}\right)_{2} \mathrm{SO}_{4}$ & Organic matter \\
\hline$\rho\left[\mathrm{kg} \mathrm{m}^{-3}\right]$ & 1720 & 1830 & 1780 & 1769 & 1400 \\
$\kappa$ & 0.67 & 0.92 & 0.61 & 0.61 & 0.1 \\
\hline
\end{tabular}

Maso et al., 2005)

$J_{\text {nuc }}=\frac{\mathrm{d} N_{\text {nuc }}}{\mathrm{d} t}+F_{\text {coag }}+F_{\text {growth }}$.

In this study, $N_{\text {nuc }}$ is the number concentration of nucleation mode particles ranging from 3 to $25 \mathrm{~nm}$. $F_{\text {growth }}$ is the flux of particles out of the specified size range $(3-25 \mathrm{~nm})$. The newly formed particles rarely grew beyond $25 \mathrm{~nm}$ before formation ended, and $F_{\text {growth }}$ can be neglected. $F_{\text {coag }}$ represents a loss of formed particles due to coagulation to the preexisting particle population. It can be calculated from the following equation:

$F_{\text {coag }}=\mathrm{CoagS}_{\text {nuc }} N_{\text {nuc }}$,

where Coag $\mathrm{S}_{\text {nuc }}$ is the coagulation sink of particles in the nucleation mode. The detailed calculation of coagulation sink is given in Dal Maso et al. (2005).

The observed particle growth rate $\left(\mathrm{GR}_{\mathrm{obs}}\right)$ can be expressed as

$\mathrm{GR}_{\mathrm{obs}}=\frac{\Delta D_{\mathrm{m}}}{\Delta t}$,

where $D_{\mathrm{m}}$ is a geometric mean diameter of lognormal ultrafine particle mode, which has been fitted to the number size distribution (Heintzenberg, 1994). $\mathrm{GR}_{\mathrm{obs}}$ means evolution of the mean diameter within a time period $\Delta t$.

\subsection{Particle growth contributed by $\mathrm{H}_{2} \mathrm{SO}_{4}$ condensation}

Theoretically, the vapor concentration required for growth rate of $1 \mathrm{~nm} \mathrm{~h}^{-1}$ in certain particle size ranges can be calculated according to (Nieminen et al., 2010)

$$
\begin{aligned}
C_{\mathrm{GR}=1 \mathrm{nmh}^{-1}} & =\frac{2 \rho_{\mathrm{v}} d_{\mathrm{v}}}{\gamma m_{\mathrm{v}} \Delta t} \cdot \sqrt{\frac{\pi m_{\mathrm{v}}}{8 k T}} \cdot\left[\frac{2 x_{1}+1}{x_{1}\left(x_{1}+1\right)}\right. \\
& \left.-\frac{2 x_{0}+1}{x_{0}\left(x_{0}+1\right)}+2 \ln \left(\frac{x_{1}\left(x_{0}+1\right)}{x_{0}\left(x_{1}+1\right)}\right)\right] .
\end{aligned}
$$

Here, $x_{0}$ and $x_{1}$ are the ratios of the vapor molecule diameter $\left(d_{\mathrm{v}}\right)$ to the initial and final particle diameter, respectively. The mass $\left(m_{\mathrm{v}}\right)$ and density $\left(\rho_{\mathrm{v}}\right)$ of sulfuric acid applied in this study are $135 \mathrm{amu}$ and $1650 \mathrm{~kg} \mathrm{~m}^{-3}$, respectively, corresponding to hydrated sulfuric acid molecules (Kurtén et al., 2007). It should be mentioned that Eq. (13) was developed specifically for particles with diameters of 3-7 nm. For larger particles $(>10 \mathrm{~nm})$, this method gives similar results to that calculated using the Fuchs-Sutugin approach (Nieminen et

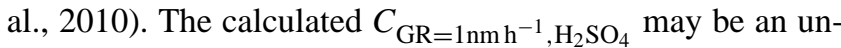
derestimate because it is assumed that every sulfuric acid molecule collided with and attached to the particle, which is not necessarily the case.

Then the growth rate contributed by sulfuric acid during the time period used for the determination of GR is calculated directly as

$\mathrm{GR}_{\mathrm{H}_{2} \mathrm{SO}_{4}}=\left[\mathrm{H}_{2} \mathrm{SO}_{4}\right]_{\mathrm{est}} / C_{\mathrm{GR}=1 \mathrm{nmh}^{-1}, \mathrm{H}_{2} \mathrm{SO}_{4}}$,

where $\left[\mathrm{H}_{2} \mathrm{SO}_{4}\right]_{\text {est }}$ is the median value from the estimated sulfuric acid concentration during the time frame for the determination of GR.

The observed growth rate can be presented as the sum of the growth rates due to $\mathrm{H}_{2} \mathrm{SO}_{4}\left(\mathrm{GR}_{\mathrm{H}_{2} \mathrm{SO}_{4}}\right)$ and organic vapor $\left(\mathrm{GR}_{\mathrm{org}}\right.$ ) condensation (Paasonen et al., 2010):

$\mathrm{GR}_{\mathrm{obs}}=\mathrm{GR}_{\mathrm{H}_{2} \mathrm{SO}_{4}}+\mathrm{GR}_{\text {org }}$.

By combining Eqs. (13)-(15), the overall particle volume change can be separated into two fraction contributing by $\mathrm{H}_{2} \mathrm{SO}_{4}$ and organic vapor condensation.

\section{Results}

\subsection{Particle formation and growth}

The previous study on the basis of long-term observations showed that the NPF events take place frequently at Melpitz, especially on April, May, and June (Hamed et al., 2010). During our field campaign (from 23 May to 8 June in 2008), the NPF events were also observed frequently. In the present study, three NPF events, which consecutively took place from 5 to 7 June 2008, as displayed in Fig. 1a, are selected for further analysis. These events are the best cases which showed clear particle bursts and subsequent growth process during the entire field campaign. The starting and ending time for each event are marked in Fig. 1a as NPF1, NPF2, and NPF3. The bursts in number concentration of $3-10 \mathrm{~nm}$ particles were observed to be associated with increasing ambient temperature, decreasing relative humidity (shown in Fig. 2b), and increasing estimated $\mathrm{H}_{2} \mathrm{SO}_{4}$ concentration (shown in Fig. 1b). The CS is between 0.01 and $0.02 \mathrm{~s}^{-1}$ during the NPF events. As marked in Fig. 1a, the particle number size distribution shows that the new particle formed around 10:00 LT (local time) and then grew 


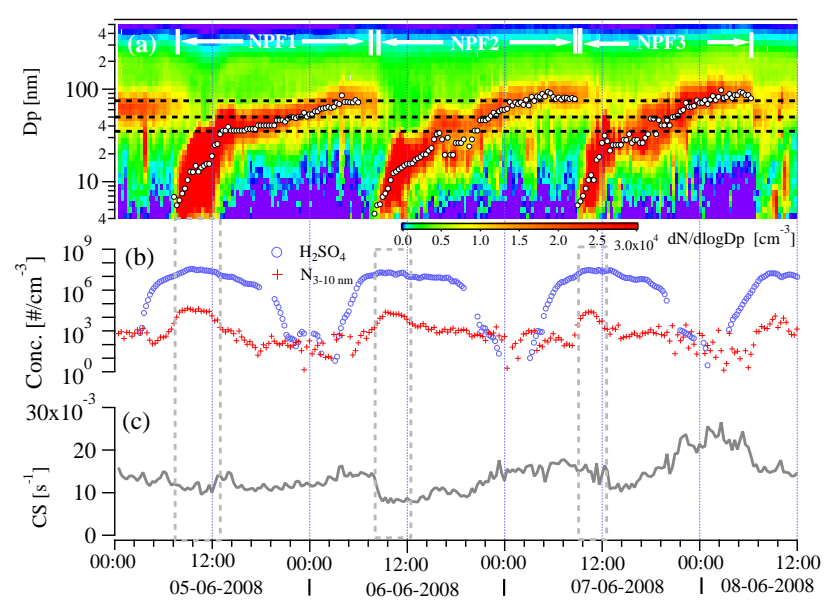

Figure 1. Particle number size distribution (a), 3-10 nm particle number concentration and $\mathrm{H}_{2} \mathrm{SO}_{4}$ concentration (b), and condensation sink (CS) (c) during the NPF events. The starting and ending times of the events are marked at the top of panel (a) by NPF1, NPF2, and NPF3. The black circles in the panel (a) are the $D_{\mathrm{m}}$ of new particles modes. The grey dashed lines indicated the time period of particle formation. The black dashed lines in panel (a) indicate the particle sizes of 35,50 , and $75 \mathrm{~nm}$. In the panel (b), the particle number concentration and $\mathrm{H}_{2} \mathrm{SO}_{4}$ concentration share the same $y$ axis and the unit.

with time for more than $20 \mathrm{~h}$. This means that the NPF is a regional event (refer to Hussein et al., 2000) and could take place over a distance of $100 \mathrm{~km}$. Figure 2a displays the wind speed and wind direction during the NPF events. The wind showed a typical diurnal cycle. The wind speed was 4-5 $\mathrm{m} \mathrm{s}^{-1}$ and kept a constant direction (south) during the daytime. The wind was static during nighttime. The particle formation rates $\left(J_{3-25 \mathrm{~nm}}\right)$ were $13.5,6.1$, and $9.3 \mathrm{~cm}^{-3} \mathrm{~s}^{-1}$ on 5, 6, and 7 June, respectively. The highest formation rate was observed on 5 June, corresponding to the highest $\mathrm{H}_{2} \mathrm{SO}_{4}$ concentration.

As indicated by the black circle in Fig. 1a, the $D_{\mathrm{m}}$ of lognormal ultrafine particle mode increased to around $100 \mathrm{~nm}$ within $24 \mathrm{~h}$. Over the time period from the beginning to the end of the NPF events as marked in Fig. 1a, the average $\mathrm{GR}_{\text {obs }}$ values were respectively $2.8,3.6$, and $4.4 \mathrm{~nm} \mathrm{~h}^{-1}$ for NPF events on 5, 6, and 7 June 2008. It should be noted that the newly formed particles continued growing during the nighttime when sulfuric acid concentration was close to zero. This indicated that other species, most likely organic compounds, contributed to the particle growth during this time period.

There were no local emission sources in the surrounding areas of the Melpitz research station. The possible primary emissions contributing to the atmospheric particles at Melpitz could come from cities in the area, which are tens of kilometers away from the station. Typically, the primary particles are accompanied by trace gases, such as $\mathrm{NO}$ and $\mathrm{SO}_{2}$

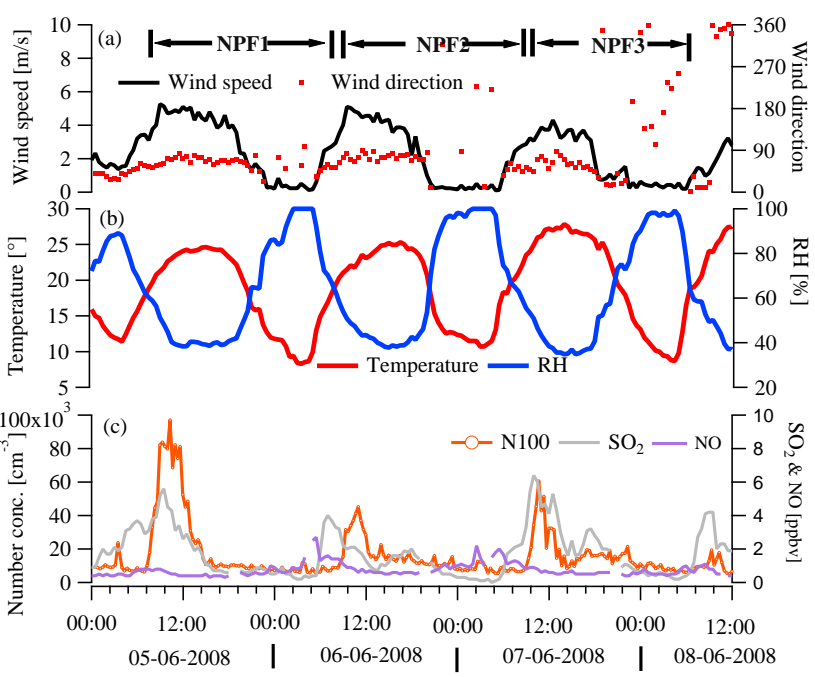

Figure 2. Time series of wind speed and wind direction (a), ambient temperature and $\mathrm{RH}(\mathbf{b})$, and $\mathrm{SO}_{2}$ and $\mathrm{NO}$ concentrations and number concentrations of particles in diameters of 3-100 nm (c). The starting and ending times of the events are marked at the top of (a) by NPF1, NPF2, and NPF3.

spikes. However, such phenomena were not observed in our measurements at Melpitz. As shown in Fig. 2c, in the early morning on 6 and 7 June, the slight enhancement of NO (a tracer for traffic-related ultrafine particles; Janhäll et al., 2004) concentration may be caused by the outflow of cities close to Melpitz. The particle number concentration did not increase simultaneously. The ultrafine particles emitted from car exhausts in the cities may grow by condensation and coagulation and shift towards larger diameters and be significantly diluted by fresh air with increasing distance from the roads (Zhu et al., 2002). As a result, the enhancement in ultrafine particle number concentration was not observed at the rural site of Melpitz. Therefore, the instant impacts of primary emissions on atmospheric particles were not observed during the time period focused in this study. $\mathrm{SO}_{2}$ from primary emissions could contribute to the atmospheric nucleation after being oxidized to sulfuric acid by radicals. The new particle formation associated with enhanced $\mathrm{SO}_{2}$ concentration has been observed by many previous studies (e.g., Birmili and Wiedensohler, 2000). Overall, the new particle formation and subsequent growth is the major source of particles and thus CCN at Melpitz station.

\subsection{Hygroscopicity and chemical composition of newly formed particles}

Figure 3 displays the size-resolved particle hygroscopicity (panel a); $m / z 44$ and 57 mass concentrations (panel b); and mass fraction of organic, sulfate, nitrate, and ammonium in $30-100 \mathrm{~nm}$ (mobility diameter) particles (panel c). As shown in Fig. 3a, peak daily $\kappa$ values of 50, 75, and $110 \mathrm{~nm}$ particles occurred afternoon and minimum appeared 
Table 3. The water-soluble fraction of newly formed particles and the ratios of $\mathrm{H}_{2} \mathrm{SO}_{4}$ condensational growth to the observed particle growth.

\begin{tabular}{|c|c|c|c|c|c|c|}
\hline$D_{\mathrm{p}}$ & \multicolumn{2}{|c|}{$35 \mathrm{~nm}$} & \multicolumn{2}{|c|}{$50 \mathrm{~nm}$} & \multicolumn{2}{|c|}{$75 \mathrm{~nm}$} \\
\hline Date & $\varepsilon$ & $F_{\mathrm{GR}_{\mathrm{H}_{2}} \mathrm{SO}_{4}}^{*}$ & $\varepsilon$ & $F_{\mathrm{GR}_{\mathrm{H}_{2} \mathrm{SO}_{4}}}$ & $\varepsilon$ & $F_{\mathrm{GR}_{\mathrm{H}_{2}} \mathrm{SO}_{4}}$ \\
\hline 5 June 2008 & - & & $24 \%$ & $23 \%$ & $20 \%$ & $15 \%$ \\
\hline 6 June 2008 & $25 \%$ & $23 \%$ & $14 \%$ & $17 \%$ & $10 \%$ & $11 \%$ \\
\hline 7 June 2008 & $34 \%$ & $30 \%$ & $23 \%$ & $20 \%$ & $17 \%$ & $13 \%$ \\
\hline
\end{tabular}

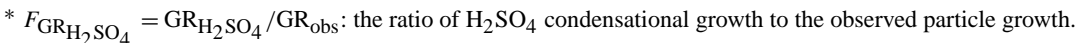
Here, $\mathrm{GR}_{\mathrm{obs}}$ values for 35,50 , and $75 \mathrm{~nm}$ were calculated over the time period during which $D_{\mathrm{m}}$ of lognormal ultrafine particle mode grew to 35,50 , and $75 \mathrm{~nm}$, respectively, as indicated by the white circles in Fig. $1 \mathrm{a}$.

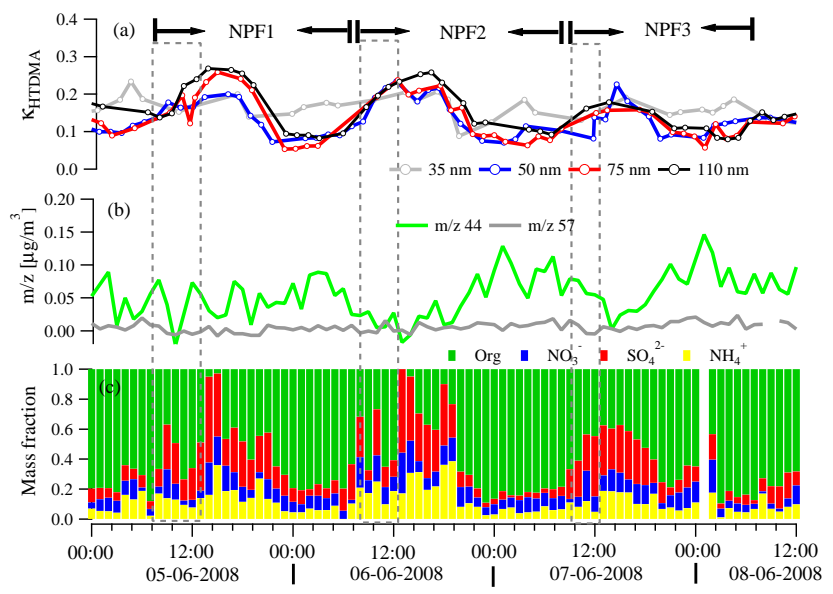

Figure 3. Size-resolved particle hygroscopicity (a); $m / z 44$ and 57 mass concentrations in $30-100 \mathrm{~nm}$ particles (b); and mass fraction of organic, sulfate, nitrate, and ammonium in 30-100 nm particles (c). The grey dashed lines indicated the time period of particle formation.

in the midnight. The evolution of particle hygroscopicity was very similar to that of the inorganic mass fraction (sulfate + nitrate + ammonium) in $30-100 \mathrm{~nm}$ particles. During the daytime, $\mathrm{H}_{2} \mathrm{SO}_{4}$ concentration increased and may have condensed onto the particles. At the same time, the increasing ambient temperature (see Fig. 2b) could drive the semivolatile organic species in the particle phase to partition to the gas phase. Both processes could result in an enhanced inorganic mass fraction in particle phase and thereby enhancement in particle hygroscopicity. The decline in particle hygroscopicity took place after 15:30 LT, when sulfuric acid concentration decreased significantly. Simultaneously, ambient temperature decreased to an eventual nighttime minimum of around $10^{\circ} \mathrm{C}$. Lower temperature facilitates the condensation of semi-volatile organic vapors onto the particles. As a result, the organic mass fraction increased significantly during the nighttime, as shown by AMS measurements (Fig. 3c), leading to an evident decline in particle hygroscopicity.

Table 3 summarizes the equivalent water-soluble fraction of newly formed particles when these particles grew to 35,50 , and $75 \mathrm{~nm}$, respectively. Here, the equivalent water- soluble fraction is corresponding to the H-TDMA measurement points at which the $D_{\mathrm{m}}$ of the ultrafine particle mode reached 35,50 , and $75 \mathrm{~nm}$. On 7 June, the equivalent watersoluble fraction of $35 \mathrm{~nm}$ newly formed particles was $34 \%$. It decreased to $23 \%$ when particle grew to $50 \mathrm{~nm}$ and further reduced to $17 \%$ when particles reached $75 \mathrm{~nm}$. On 5 and 6 June, the hygroscopicity of newly formed particles decreased with increasing particle size as well. This implies that a large fraction of species contributing to particle growth was organics, which are typically less water soluble. This can be confirmed by AMS measurements showing that organic fraction in particles increased at a relatively later time of the NPF event (see Fig. 3c). The contribution of $\mathrm{H}_{2} \mathrm{SO}_{4}$ condensation to particle growth was estimated using the method introduced in Sect. 3.5 for different particle sizes. The ratios of $\mathrm{H}_{2} \mathrm{SO}_{4}$ condensational growth to the observed par-

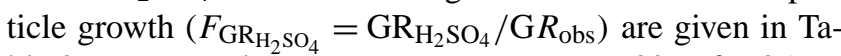
ble 3. For example, on 7 June, $F_{\mathrm{GR}_{\mathrm{H}_{2} \mathrm{SO}_{4}}}$ was $30 \%$ for $35 \mathrm{~nm}$ particles, meaning that $\mathrm{H}_{2} \mathrm{SO}_{4}$ condensation only contributed $30 \%$ of the observed particle growth. With increasing particle size, the contribution of $\mathrm{H}_{2} \mathrm{SO}_{4}$ condensation decreased, as shown in Table 3. This was consistent with the changes in the equivalent water-soluble fraction of newly formed particles. Both particle hygroscopicity measurements and numerical analysis showed that organics were potentially major contributors to the particle growth.

As displayed in Fig. 3c, the organic compounds were dominating species in $30-100 \mathrm{~nm}$ particles in the particle formation period (indicated by grey dashed lines). In this period, most of newly formed particles were smaller than $30 \mathrm{~nm}$, as shown in Fig. 1a. These particles are too small to be detected by HR-ToF-AMS. Therefore, AMS measurements cannot provide proper information on chemical composition of newly formed particles in the particle formation period. After around 12:00 LT, the newly formed particles grew beyond $30 \mathrm{~nm}$. Simultaneously, an obvious increase in sulfate and ammonium mass fraction in $30-100 \mathrm{~nm}$ particles was observed. This indicates that the newly formed particles were dominated by sulfate and ammonium. After 15:00 LT, the organic mass fraction increased and reached its maximum at midnight on each day, indicating that organics played a key role in the particle growth at a later time of the NPF event. 


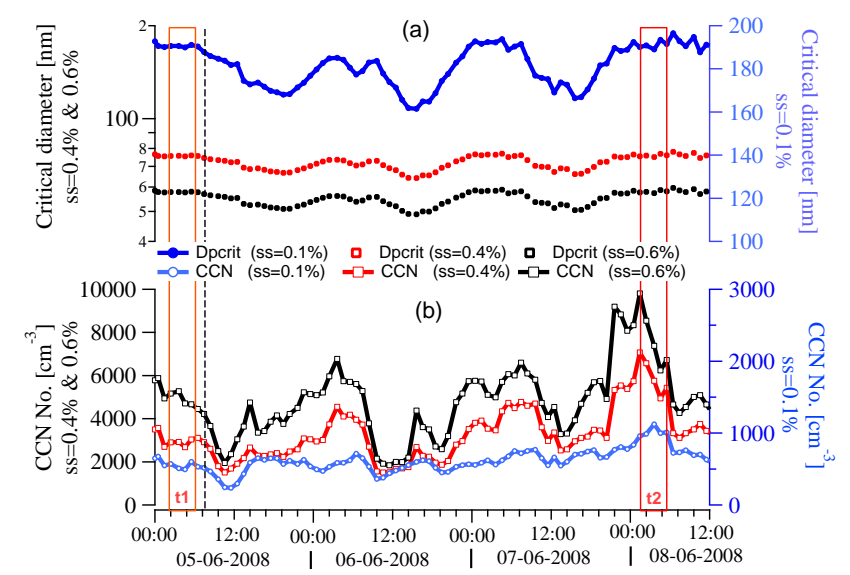

Figure 4. Critical diameter (Dpcrit) and $\mathrm{CCN}$ number concentration during NPF events.

The mass fractions of ion fragments $m / z 44$ and 57 in 30$100 \mathrm{~nm}$ particles are shown in Fig. 3b. The $m / z 44\left(\mathrm{CO}_{2}^{+}\right.$ion fragment) is a tracer for secondary organic aerosol, while $m / z 57\left(\mathrm{C}_{4} \mathrm{H}_{9}^{+}\right)$is generally associated with primary organics from combustion sources (Q. Zhang et al., 2004). The $m / z 57$ mass concentration was close to zero during the events. Compared $m / z 57$, the $m / z 44$ mass concentrations were considerable, indicating that the organics contributing to particle growth were mainly secondary organic species.

\subsection{Enhancement in $\mathrm{CCN}$ number concentration during the NPF events}

The critical diameters and CCN number concentrations at different supersaturations during the NPF events are displayed in Fig. 4. The critical diameters at different supersaturations decreased during the first few hours of the NPF events and enhanced at a later time of the NPF event. This was consistent with the variations in particle hygroscopic growth at $\mathrm{RH}=90 \%$ mentioned above (see Fig. 3a). As shown in Fig. $4 \mathrm{~b}$, the $\mathrm{CCN}$ number concentration clearly increased significantly during the NPF events. The minimum in CCN number concentration was observed during the period of particle formation, and the maximum appeared at the end of the NPF events.

The NPF events that occurred on 5, 6, and 7 June were typical regional cases. The enhancement in $\mathrm{CCN}$ number concentration caused by atmospheric nucleation was evaluated by comparing the average $\mathrm{CCN}$ number concentrations over $2 \mathrm{~h}$ prior to the beginning of the event (the period $\mathrm{t} 1$ marked in Fig. 4) with the same time period before the end of the events (the period $t 2$ marked in Fig. 4). The ratios of average $\mathrm{CCN}$ number concentration over $\mathrm{t} 2$ to $\mathrm{t} 1$ were respectively $1.9,2.0$, and 1.5 for $0.1,0.4$, and $0.6 \%$ SS. On average, the enhancement ratios in $\mathrm{CCN}$ number concentration associated with individual NPF events were 63,66 , and $69 \%$ for $0.1,0.4$, and $0.6 \% \mathrm{SS}$, respectively. The absolute increases in $\mathrm{CCN}$ number concentrations associated with each event were on average 162,931 , and $756 \# \mathrm{~cm}^{-3}$.

Atmospheric boundary layer development and turbulent mixing will impact on NPF (Boy et al., 2006, 2003; Altstädter et al., 2015), and consequently on its $\mathrm{CCN}$ products. It is a difficult task to quantify the changes in $\mathrm{CCN}$ number due to boundary layer dynamics. In this study, the enhancement in CCN number concentration caused by atmospheric nucleation was evaluated by a ratio of $\mathrm{CCN}$ numbers during the same period on different days, and not an absolute value. Here we assume that the weather condition and boundary layer height were similar during two time periods (see meteorological parameters in Fig. 3). Therefore, we assumed that the effect of boundary layer dynamics on the change in $\mathrm{CCN}$ number concentration could be ignored.

Several previous studies have reported that the enhancement in CCN number concentration associated with atmospheric nucleation varied significantly in different environments. At the Finnish subarctic Pallas station, a $210 \pm 110 \%$ increase in the number concentration of $80 \mathrm{~nm}$ particles was observed from the beginning of a nucleation event to the end of the event (Asmi et al., 2011). At a forested site (SMEAR II station in Hyytiälä) in southern Finland, nucleation enhanced CCN number concentration by 70 to $110 \%$, varying with the supersaturation level (Sihto et al., 2011). In a polluted urban area, Beijing, China, the average CCN enhancement factors were between about 1.5 and 2.5 (Yue et al., 2011; Wiedensohler et al., 2009). In Boulder, CO; Atlanta, GA; and Tecámac, Mexico, the preexisting $\mathrm{CCN}$ number concentration increased on average by a factor of 3.8 as a result of new particle formation (Kuang et al., 2009). Overall, the enhancement in $\mathrm{CCN}$ number concentration associated with atmospheric nucleation varied significantly in different environments. Please note that the methods for defining the enhancement factors used in the existing literature were very different. Therefore, a general conclusion on how significant $\mathrm{NPF}$ and growth process contributes to $\mathrm{CCN}$ budget cannot currently be drawn.

\section{Discussion}

The above field observations clearly showed that newly formed particles had the ability to grow into $\mathrm{CCN}$ sizes within several hours at Melpitz. The particle hygroscopicity measurements strongly suggested that organic compounds were the major contributors driving particle growth into CCN sizes. The previous studies performed in clean atmosphere also showed that the newly formed particles mainly consist of organics. For examples, sulfuric acid is able to account for roughly $30 \%$ of the growth rate of newly formed particles in the rural atmosphere of Hohenpeissenberg, southern Germany (Birmili et al., 2003), and only around $10 \%$ in the boreal forest area of Finland (Boy et al., 2005). However, in the polluted atmosphere of Atlanta, USA, the available amount 
of sulfuric acid was sufficient to explain all of the observed particle growth (Stolzenburg et al., 2005). At Melpitz, biogenic volatile organic compounds (BVOCs) emitted from biological activities are dominant volatile organic compounds (Mutzel et al., 2015) and lead to an organic-rich environment during the summertime. The oxidation products of BVOCs may be responsible for the new particle growth.

We note that the condensation of organics led to rapid particle growth when sulfuric acid concentration was close to zero during the nighttime, as shown in Fig. 1. The organic condensing materials with low hygroscopicity reduced CCN efficiency of the new particles, as indicated by critical diameters given in Fig. 4. Such a phenomenon was also reported by Dusek et al. (2010), who showed that enhanced organic mass fraction caused a reduction in $\mathrm{CCN}$ efficiency of small particles during the new particle formation. These results imply that the CCN production associated with atmospheric nucleation may be overestimated if assuming that new particles can serve as CCN once they grow to a fixed particle size (such as Asmi et al., 2011), especially for organic-rich environments. In our case, the mean critical diameter is around $50 \mathrm{~nm}$ at $\mathrm{SS}=0.6 \%$. Assuming a constant critical diameter of $50 \mathrm{~nm}$ at $\mathrm{SS}=0.6 \%$, the CCN number concentration was on average 1.13 times greater than that with varied critical diameters during the NPF events. Under similar conditions, the $\mathrm{CCN}$ number concentration at $\mathrm{SS}=0.4 \%$ with a constant critical diameter of $70 \mathrm{~nm}$ was 1.15 times greater than that with varied critical diameters.

\section{Conclusions}

In this study, the particle number size distribution, particle hygroscopicity, and particle chemical composition during three regional NPF events were measured to investigate the new particle growth process and its effects on CCN activity. The particle formation rates $\left(J_{3-25 \mathrm{~nm}}\right)$ were $13.5,6.1$, and $9.3 \mathrm{~cm}^{-3} \mathrm{~s}^{-1}$, and the particle growth rates were 2.8, 3.6, and $4.4 \mathrm{~nm} \mathrm{~h}^{-1}$ for NPF events on 5, 6, and 7 June 2008, respectively.

The $\left(\mathrm{NH}_{4}\right)_{2} \mathrm{SO}_{4}$-equivalent water-soluble fraction accounted for 20 and $16 \%$ of 50 and $75 \mathrm{~nm}$ newly formed particles, respectively. AMS measurements showed that the sulfate and ammonium were dominant chemical species when newly formed particles grew beyond $30 \mathrm{~nm}$ shortly after the particle formation period. At a later time of NPF event, the organics played a key role in the particle growth. The analysis on the fragment $m / z 44$ and 57 showed that the organics contributing to particle growth were mainly secondary organic species. The particle hygroscopicity and chemical composition measurements and numerical calculation confirmed that organic compounds were major contributors driving particles' growth to $\mathrm{CCN}$ sizes.
A step-wise increase in $\mathrm{CCN}$ number concentration during three consecutive NPF events was observed. On average, the enhancement ratios in $\mathrm{CCN}$ number concentration associated with individual NPF events are 63, 66, and $69 \%$ for 0.1 , 0.4 , and $0.6 \% \mathrm{SS}$, respectively. We found that the new particles' hygroscopicity decreased significantly with condensational growth of organic compounds, which are generally less water soluble. Correspondingly, the critical diameters at a certain supersaturation increased, indicating that enhanced organic mass fraction caused a reduction in $\mathrm{CCN}$ efficiency of newly formed particles during the new particle formation. Our results implied that the $\mathrm{CCN}$ production associated with atmospheric nucleation may be overestimated if assuming that new particles can serve as $\mathrm{CCN}$ once they grow to a fixed particle size, an assumption made in some previous studies, especially for organic-rich environments.

Acknowledgements. The data analysis work done by the first author was supported by National Natural Science Foundation of China (41475127). Data collection was supported by the European Commission projects EUSAAR (European Supersites for Atmospheric Aerosol Research) and EUCAARI (European Integrated project on Aerosol Cloud Climate and Air Quality Interactions; FP6-036833-2-EUCAARI) and through the German Federal Environment Ministry (BMU) grant F\&E 370343200. We acknowledge Friederike Kinder, Andreas Maßling, and Thomas Tuch for their contributions related to H-TDMA and TDMPS data acquisition.

Edited by: V.-M. Kerminen

\section{References}

Altstädter, B., Platis, A., Wehner, B., Scholtz, A., Wildmann, N., Hermann, M., Käthner, R., Baars, H., Bange, J., and Lampert, A.: ALADINA - an unmanned research aircraft for observing vertical and horizontal distributions of ultrafine particles within the atmospheric boundary layer, Atmos. Meas. Tech., 8, 16271639, doi:10.5194/amt-8-1627-2015, 2015.

Asmi, E., Kivekäs, N., Kerminen, V.-M., Komppula, M., Hyvärinen, A.-P., Hatakka, J., Viisanen, Y., and Lihavainen, H.: Secondary new particle formation in Northern Finland Pallas site between the years 2000 and 2010, Atmos. Chem. Phys., 11, 12959-12972, doi:10.5194/acp-11-12959-2011, 2011.

Birmili, W. and Wiedensohler, A.: New particle formation in the continental boundary layer: Meteorological and gas phase parameter influence, Geophys. Res. Lett., 27, 3325-3328, 10.1029/1999GL011221, 2000.

Birmili, W., Stratmann, F., and Wiedensohler, A.: Design of a DMA-based size spectrometer for a large particle size range and stable operation, J. Aerosol Sci., 30, 549-553, 1999.

Birmili, W., Berresheim, H., Plass-Dülmer, C., Elste, T., Gilge, S., Wiedensohler, A., and Uhrner, U.: The Hohenpeissenberg aerosol formation experiment (HAFEX): a long-term study including size-resolved aerosol, $\mathrm{H}_{2} \mathrm{SO}_{4}, \mathrm{OH}$, and monoter- 
penes measurements, Atmos. Chem. Phys., 3, 361-376, doi:10.5194/acp-3-361-2003, 2003.

Birmili, W., Weinhold, K., Nordmann, S., Wiedensohler, A., Spindler, G., Müller, K., Herrmann, H., Gnauk, T., Pitz, M., Cyrys, J., Flentje, H., Nickel, C., Kuhlbusch, T. A. J., and Löschau, G.: Atmospheric aerosol measurements in the German Ultrafine Aerosol Network (GUAN): Part 1 - soot and particle number size distribution, Gefahrst. Reinh. Luft., 69, 137-145, 2009.

Boy, M., Rannik, Ü., Lehtinen, K. E. J., Tarvainen, V., Hakola, H., and Kulmala, M.: Nucleation events in the continental boundary layer: Long-term statistical analyses of aerosol relevant characteristics, J. Geophys. Res.-Atmos., 108, 4667, doi:10.1029/2003JD003838, 2003.

Boy, M., Kulmala, M., Ruuskanen, T. M., Pihlatie, M., Reissell, A., Aalto, P. P., Keronen, P., Dal Maso, M., Hellen, H., Hakola, H., Jansson, R., Hanke, M., and Arnold, F.: Sulphuric acid closure and contribution to nucleation mode particle growth, Atmos. Chem. Phys., 5, 863-878, doi:10.5194/acp-5-863-2005, 2005.

Boy, M., Hellmuth, O., Korhonen, H., Nilsson, E. D., ReVelle, D., Turnipseed, A., Arnold, F., and Kulmala, M.: MALTE - model to predict new aerosol formation in the lower troposphere, Atmos. Chem. Phys., 6, 4499-4517, doi:10.5194/acp-6-4499-2006, 2006.

Brus, D., Neitola, K., Hyvärinen, A.-P., Petäjä, T., Vanhanen, J., Sipilä, M., Paasonen, P., Kulmala, M., and Lihavainen, H.: Homogenous nucleation of sulfuric acid and water at close to atmospherically relevant conditions, Atmos. Chem. Phys., 11, 52775287, doi:10.5194/acp-11-5277-2011, 2011.

Canagaratna, M. R., Jayne, J. T., Jimenez, J. L., Allan, J. D., Alfarra, M. R., Zhang, Q., Onasch, T. B., Drewnick, F., Coe, H., Middlebrook, A., Delia, A., Williams, L. R., Trimborn, A. M., Northway, M. J., DeCarlo, P. F., Kolb, C. E., Davidovits, P., and Worsnop, D. R.: Chemical and microphysical characterization of ambient aerosols with the aerodyne aerosol mass spectrometer, Mass Spectrom. Rev., 26, 185-222, doi:10.1002/mas.20115, 2007.

Cerully, K. M., Raatikainen, T., Lance, S., Tkacik, D., Tiitta, P., Petäjä, T., Ehn, M., Kulmala, M., Worsnop, D. R., Laaksonen, A., Smith, J. N., and Nenes, A.: Aerosol hygroscopicity and CCN activation kinetics in a boreal forest environment during the 2007 EUCAARI campaign, Atmos. Chem. Phys., 11, 12369-12386, doi:10.5194/acp-11-12369-2011, 2011.

Dal Maso, M., Kulmala, M., Riipinen, I., Wagner, R., Hussein, T., Aalto, P. P., and Lehtinen, K. E.: Formation and growth of fresh atmospheric aerosols: eight years of aerosol size distribution data from SMEAR II, Hyytiala, Finland, Boreal Environ. Res., 10, 323-336, 2005.

DeCarlo, P. F., Kimmel, J. R., Trimborn, A., Northway, M. J., Jayne, J. T., Aiken, A. C., Gonin, M., Fuhrer, K., Horvath, T., Docherty, K. S., Worsnop, D. R., and Jimenez, J. L.: Field-Deployable, High-Resolution, Time-of-Flight Aerosol Mass Spectrometer, Anal. Chem., 78, 8281-8289, doi:10.1021/ac061249n, 2006.

Dusek, U., Frank, G. P., Hildebrandt, L., Curtius, J., Schneider, J., Walter, S., Chand, D., Drewnick, F., Hings, S., Jung, D., Borrmann, S., and Andreae, M. O.: Size Matters More Than Chemistry for Cloud-Nucleating Ability of Aerosol Particles, Science, 312, 1375-1378, doi:10.1126/science.1125261, 2006.
Dusek, U., Frank, G. P., Curtius, J., Drewnick, F., Schneider, J., Kürten, A., Rose, D., Andreae, M. O., Borrmann, S., and Pöschl, U.: Enhanced organic mass fraction and decreased hygroscopicity of cloud condensation nuclei (CCN) during new particle formation events, Geophys. Res. Lett., 37, L03804, doi:10.1029/2009GL040930, 2010.

Ehn, M., Petäjä, T., Aufmhoff, H., Aalto, P., Hämeri, K., Arnold, F., Laaksonen, A., and Kulmala, M.: Hygroscopic properties of ultrafine aerosol particles in the boreal forest: diurnal variation, solubility and the influence of sulfuric acid, Atmos. Chem. Phys., 7, 211-222, doi:10.5194/acp-7-211-2007, 2007.

Good, N., Topping, D. O., Allan, J. D., Flynn, M., Fuentes, E., Irwin, M., Williams, P. I., Coe, H., and McFiggans, G.: Consistency between parameterisations of aerosol hygroscopicity and CCN activity during the RHaMBLe discovery cruise, Atmos. Chem. Phys., 10, 3189-3203, doi:10.5194/acp-10-3189-2010, 2010.

Größ, J., Birmili, W., Hamed, A., Sonntag, A., Wiedensohler, A., Spindler, G., Maninnen, H. E., Nieminen, T., Kulmala, M., Hõrrak, U., and Plass-Dülmer, C.: Evolution of gaseous precursors and meteorological parameters during new particle formation events in the Central European boundary layer, Atmos. Chem. Phys. Discuss., 15, 2305-2353, doi:10.5194/acpd-152305-2015, 2015.

Gysel, M., Crosier, J., Topping, D. O., Whitehead, J. D., Bower, K. N., Cubison, M. J., Williams, P. I., Flynn, M. J., McFiggans, G. B., and Coe, H.: Closure study between chemical composition and hygroscopic growth of aerosol particles during TORCH2, Atmos. Chem. Phys., 7, 6131-6144, doi:10.5194/acp-7-61312007, 2007.

Gysel, M., McFiggans, G. B., and Coe, H.: Inversion of tandem differential mobility analyser (TDMA) measurements, J. Aerosol Sci., 40, 134-151, doi:10.1016/j.jaerosci.2008.07.013, 2009.

Hamed, A., Birmili, W., Joutsensaari, J., Mikkonen, S., Asmi, A., Wehner, B., Spindler, G., Jaatinen, A., Wiedensohler, A., Korhonen, H., Lehtinen, K. E. J., and Laaksonen, A.: Changes in the production rate of secondary aerosol particles in Central Europe in view of decreasing $\mathrm{SO}_{2}$ emissions between 1996 and 2006, Atmos. Chem. Phys., 10, 1071-1091, doi:10.5194/acp-10-10712010, 2010.

Hämeri, K., Väkevä, M., Aalto, P. P., Kulmala, M., Swietlicki, E., Zhou, J., Seidl, W., Becker, E., and O'Dowd, C. D.: Hygroscopic and CCN properties of aerosol particles in boreal forests, Tellus B, 53, 359-379, doi:10.1034/j.1600-0889.2001.530404.x, 2001.

Heintzenberg, J.: Properties of the Log-Normal Particle Size Distribution, Aerosol Sci. Technol., 21, 46-48, doi:10.1080/02786829408959695, 1994.

Hussein, T., Aalto, P. P., and Lehtinen, K. E. J.: Formation and growth of fresh atmospheric aerosols: eight years of aerosol size distribution data from SMEAR II, Hyytiälä, Finland, 2000.

Irwin, M., Good, N., Crosier, J., Choularton, T. W., and McFiggans, G.: Reconciliation of measurements of hygroscopic growth and critical supersaturation of aerosol particles in central Germany, Atmos. Chem. Phys., 10, 11737-11752, doi:10.5194/acp10-11737-2010, 2010.

Janhäll, S., M. Jonsson, A., Molnár, P., A. Svensson, E., and Hallquist, M.: Size resolved traffic emission factors of submicrometer particles, Atmos. Environ., 38, 4331-4340, doi:10.1016/j.atmosenv.2004.04.018, 2004. 
Kazil, J., Stier, P., Zhang, K., Quaas, J., Kinne, S., O’Donnell, D., Rast, S., Esch, M., Ferrachat, S., Lohmann, U., and Feichter, J.: Aerosol nucleation and its role for clouds and Earth's radiative forcing in the aerosol-climate model ECHAM5-HAM, Atmos. Chem. Phys., 10, 10733-10752, doi:10.5194/acp-1010733-2010, 2010.

Kerminen, V.-M., Lehtinen, K. E. J., Anttila, T., and Kulmala, M.: Dynamics of atmospheric nucleation mode particles: a timescale analysis, Tellus B, 56, 135-146, doi:10.3402/tellusb.v56i2.16411, 2004.

Kerminen, V.-M., Paramonov, M., Anttila, T., Riipinen, I., Fountoukis, C., Korhonen, H., Asmi, E., Laakso, L., Lihavainen, H., Swietlicki, E., Svenningsson, B., Asmi, A., Pandis, S. N., Kulmala, M., and Petäjä, T.: Cloud condensation nuclei production associated with atmospheric nucleation: a synthesis based on existing literature and new results, Atmos. Chem. Phys., 12, 1203712059, doi:10.5194/acp-12-12037-2012, 2012.

Kiendler-Scharr, A., Wildt, J., Maso, M. D., Hohaus, T., Kleist, E., Mentel, T. F., Tillmann, R., Uerlings, R., Schurr, U., and Wahner, A.: New particle formation in forests inhibited by isoprene emissions, Nature, 461, 381-384, 2009

Kuang, C., McMurry, P. H., and McCormick, A. V.: Determination of cloud condensation nuclei production from measured new particle formation events, Geophys. Res. Lett., 36, L09822, doi:10.1029/2009GL037584, 2009.

Kulmala, M., Laakso, L., Lehtinen, K. E. J., Riipinen, I., Dal Maso, M., Anttila, T., Kerminen, V.-M., Hõrrak, U., Vana, M., and Tammet, H.: Initial steps of aerosol growth, Atmos. Chem. Phys., 4, 2553-2560, doi:10.5194/acp-4-2553-2004, 2004.

Kulmala, M., Lehtinen, K. E. J., and Laaksonen, A.: Cluster activation theory as an explanation of the linear dependence between formation rate of $3 \mathrm{~nm}$ particles and sulphuric acid concentration, Atmos. Chem. Phys., 6, 787-793, doi:10.5194/acp-6-787-2006, 2006

Kulmala, M., Asmi, A., Lappalainen, H. K., Carslaw, K. S., Pöschl, U., Baltensperger, U., Hov, Ø., Brenquier, J.-L., Pandis, S. N., Facchini, M. C., Hansson, H.-C., Wiedensohler, A., and O'Dowd, C. D.: Introduction: European Integrated Project on Aerosol Cloud Climate and Air Quality interactions (EUCAARI) - integrating aerosol research from nano to global scales, Atmos. Chem. Phys., 9, 2825-2841, doi:10.5194/acp-9-2825-2009, 2009.

Kulmala, M., Petäjä, T., Nieminen, T., Sipilä, M., Manninen, H. E., Lehtipalo, K., Dal Maso, M., Aalto, P. P., Junninen, H., Paasonen, P., Riipinen, I., Lehtinen, K. E. J., Laaksonen, A., and Kerminen, V.-M.: Measurement of the nucleation of atmospheric aerosol particles, Nat. Protocols, 7, 1651-1667, 2012.

Kurtén, T., Torpo, L., Ding, C.-G., Vehkamäki, H., Sundberg, M. R., Laasonen, K., and Kulmala, M.: A density functional study on water-sulfuric acid-ammonia clusters and implications for atmospheric cluster formation, J. Geophys. Res.-Atmos., 112, D04210, doi:10.1029/2006JD007391, 2007.

Laakso, L., Petäjä, T., Lehtinen, K. E. J., Kulmala, M., Paatero, J., Hõrrak, U., Tammet, H., and Joutsensaari, J.: Ion production rate in a boreal forest based on ion, particle and radiation measurements, Atmos. Chem. Phys., 4, 1933-1943, doi:10.5194/acp-41933-2004, 2004.

Laakso, L., Merikanto, J., Vakkari, V., Laakso, H., Kulmala, M., Molefe, M., Kgabi, N., Mabaso, D., Carslaw, K. S., Spracklen, D.
V., Lee, L. A., Reddington, C. L., and Kerminen, V.-M.: Boundary layer nucleation as a source of new $\mathrm{CCN}$ in savannah environment, Atmos. Chem. Phys., 13, 1957-1972, doi:10.5194/acp13-1957-2013, 2013.

Laaksonen, A., Hamed, A., Joutsensaari, J., Hiltunen, L., Cavalli, F., Junkermann, W., Asmi, A., Fuzzi, S., and Facchini, M. C.: Cloud condensation nucleus production from nucleation events at a highly polluted region, Geophys. Res. Lett., 32, L06812, doi:10.1029/2004g1022092, 2005.

Malm, W. C. and Kreidenweis, S. M.: The effects of models of aerosol hygroscopicity on the apportionment of extinction, Atmos. Environ., 31, 1965-1976, doi:10.1016/s13522310(96)00355-x, 1997.

Maßling, A., Wiedensohler, A., Busch, B., Neusüß, C., Quinn, P., Bates, T., and Covert, D.: Hygroscopic properties of different aerosol types over the Atlantic and Indian Oceans, Atmos. Chem. Phys., 3, 1377-1397, doi:10.5194/acp-3-1377-2003, 2003.

Massling, A., Niedermeier, N., Hennig, T., Fors, E. O., Swietlicki, E., Ehn, M., Hämeri, K., Villani, P., Laj, P., Good, N., McFiggans, G., and Wiedensohler, A.: Results and recommendations from an intercomparison of six Hygroscopicity-TDMA systems, Atmos. Meas. Tech., 4, 485-497, doi:10.5194/amt-4-485-2011, 2011.

Merikanto, J., Spracklen, D. V., Mann, G. W., Pickering, S. J., and Carslaw, K. S.: Impact of nucleation on global CCN, Atmos. Chem. Phys., 9, 8601-8616, doi:10.5194/acp-9-8601-2009, 2009.

Mutzel, A., Poulain, L., Berndt, T., Iinuma, Y., Rodigast, M., Böge, O., Richters, S., Spindler, G., Sipilä, M., Jokinen, T., Kulmala, M., and Herrmann, H.: Highly Oxidized Multifunctional Organic Compounds Observed in Tropospheric Particles: A Field and Laboratory Study, Environ. Sci. Technol., 49, 7754-7761, doi:10.1021/acs.est.5b00885, 2015.

Nieminen, T., Lehtinen, K. E. J., and Kulmala, M.: Sub-10 nm particle growth by vapor condensation - effects of vapor molecule size and particle thermal speed, Atmos. Chem. Phys., 10, 9773 9779, doi:10.5194/acp-10-9773-2010, 2010.

Paasonen, P., Nieminen, T., Asmi, E., Manninen, H. E., Petäjä, T., Plass-Dülmer, C., Flentje, H., Birmili, W., Wiedensohler, A., Hõrrak, U., Metzger, A., Hamed, A., Laaksonen, A., Facchini, M. C., Kerminen, V.-M., and Kulmala, M.: On the roles of sulphuric acid and low-volatility organic vapours in the initial steps of atmospheric new particle formation, Atmos. Chem. Phys., 10, 11223-11242, doi:10.5194/acp-10-11223-2010, 2010.

Paasonen, P., Asmi, A., Petaja, T., Kajos, M. K., Aijala, M., Junninen, H., Holst, T., Abbatt, J. P. D., Arneth, A., Birmili, W., van der Gon, H. D., Hamed, A., Hoffer, A., Laakso, L., Laaksonen, A., Richard Leaitch, W., Plass-Dulmer, C., Pryor, S. C., Raisanen, P., Swietlicki, E., Wiedensohler, A., Worsnop, D. R., Kerminen, V.-M., and Kulmala, M.: Warming-induced increase in aerosol number concentration likely to moderate climate change, Nature Geosci., 6, 438-442, doi:10.1038/ngeo1800, 2013.

Petters, M. D. and Kreidenweis, S. M.: A single parameter representation of hygroscopic growth and cloud condensation nucleus activity, Atmos. Chem. Phys., 7, 1961-1971, doi:10.5194/acp-71961-2007, 2007.

Petters, M. D., Wex, H., Carrico, C. M., Hallbauer, E., Massling, A., McMeeking, G. R., Poulain, L., Wu, Z., Kreidenweis, S. M., and Stratmann, F.: Towards closing the gap between hygro- 
scopic growth and activation for secondary organic aerosol - Part 2: Theoretical approaches, Atmos. Chem. Phys., 9, 3999-4009, doi:10.5194/acp-9-3999-2009, 2009.

Pierce, J. R., Riipinen, I., Kulmala, M., Ehn, M., Petäjä, T., Junninen, H., Worsnop, D. R., and Donahue, N. M.: Quantification of the volatility of secondary organic compounds in ultrafine particles during nucleation events, Atmos. Chem. Phys., 11, 90199036, doi:10.5194/acp-11-9019-2011, 2011.

Pirjola, L., Kulmala, M., Wilck, M., Bischoff, A., Stratmann, F., and Otto, E.: Formation of Sulphuric Acid Aerosols And Cloud Condensation Nuclei: An Expression For Significant Nucleation And Model Comprarison, J. Aerosol Sci., 30, 1079-1094, doi:10.1016/S0021-8502(98)00776-9, 1999.

Potukuchi, S. and Wexler, A. S.: Identifying solid-aqueous phase transitions in atmospheric aerosols - I. Neutral-acidity solutions, Atmos. Environ., 29, 1663-1676, doi:10.1016/13522310(95)00074-9, 1995.

Poulain, L., Birmili, W., Canonaco, F., Crippa, M., Wu, Z. J., Nordmann, S., Spindler, G., Prévôt, A. S. H., Wiedensohler, A., and Herrmann, H.: Chemical mass balance of $300^{\circ} \mathrm{C}$ nonvolatile particles at the tropospheric research site Melpitz, Germany, Atmos. Chem. Phys., 14, 10145-10162, doi:10.5194/acp14-10145-2014, 2014.

Ristovski, Z. D., Suni, T., Kulmala, M., Boy, M., Meyer, N. K., Duplissy, J., Turnipseed, A., Morawska, L., and Baltensperger, U.: The role of sulphates and organic vapours in growth of newly formed particles in a eucalypt forest, Atmos. Chem. Phys., 10, 2919-2926, doi:10.5194/acp-10-2919-2010, 2010.

Sihto, S.-L., Mikkilä, J., Vanhanen, J., Ehn, M., Liao, L., Lehtipalo, K., Aalto, P. P., Duplissy, J., Petäjä, T., Kerminen, V.-M., Boy, M., and Kulmala, M.: Seasonal variation of CCN concentrations and aerosol activation properties in boreal forest, Atmos. Chem. Phys., 11, 13269-13285, doi:10.5194/acp-11-13269-2011, 2011.

Sipilä, M., Berndt, T., Petäjä, T., Brus, D., Vanhanen, J., Stratmann, F., Patokoski, J., Mauldin, R. L., Hyvärinen, A.-P., Lihavainen, H., and Kulmala, M.: The Role of Sulfuric Acid in Atmospheric Nucleation, Science, 327, 1243-1246, 2010.

Smith, J. N., Moore, K. F., McMurry, P. H., and Eisele, F. L.: Atmospheric Measurements of Sub-20 nm Diameter Particle Chemical Composition by Thermal Desorption Chemical Ionization Mass Spectrometry, Aerosol Sci. Technol., 38, 100-110, doi:10.1080/02786820490249036, 2004.

Sotiropoulou, R. E. P., Tagaris, E., Pilinis, C., Anttila, T., and Kulmala, M.: Modeling New Particle Formation During Air Pollution Episodes: Impacts on Aerosol and Cloud Condensation Nuclei, Aerosol Sci. Technol., 40, 557-572, doi:10.1080/02786820600714346, 2006.

Spracklen, D. V., Carslaw, K. S., Kulmala, M., Kerminen, V.-M., Sihto, S.-L., Riipinen, I., Merikanto, J., Mann, G. W., Chipperfield, M. P., Wiedensohler, A., Birmili, W., and Lihavainen, H.: Contribution of particle formation to global cloud condensation nuclei concentrations, Geophys. Res. Lett., 35, L06808, doi:10.1029/2007g1033038, 2008.

Stokes, R. H. and Robinson, R. A.: Interactions in Aqueous Nonelectrolyte Solutions. I. Solute-Solvent Equilibria, J. Phys. Chem., 70, 2126-2130, 1966.

Stolzenburg, M. R., McMurry, P. H., Sakurai, H., Smith, J. N., Mauldin, R. L., Eisele, F. L., and Clement, C. F.: Growth rates of freshly nucleated atmospheric particles in Atlanta, J. Geophys. Res.-Atmos., 110, D22S05, doi:10.1029/2005JD005935, 2005.

Swietlicki, E., Zhou, J., Berg, O. H., Martinsson, B. G., Frank, G., Cederfelt, S.-I., Dusek, U., Berner, A., Birmili, W., Wiedensohler, A., Yuskiewicz, B., and Bower, K. N.: A closure study of sub-micrometer aerosol particle hygroscopic behaviour, Atmos. Res., 50, 205-240, doi:10.1016/s0169-8095(98)00105-7, 1999.

Tang, I. N. and Munkelwitz, H. R.: Water activities, densities, and refractive indices of aqueous sulfates and sodium nitrate droplets of atmospheric importance, J. Geophys. Res., 99, 18801-18808, doi:10.1029/94jd01345, 1994.

Tuch, T. M., Haudek, A., Müller, T., Nowak, A., Wex, H., and Wiedensohler, A.: Design and performance of an automatic regenerating adsorption aerosol dryer for continuous operation at monitoring sites, Atmos. Meas. Tech., 2, 417-422, doi:10.5194/amt-2-417-2009, 2009.

Varutbangkul, V., Brechtel, F. J., Bahreini, R., Ng, N. L., Keywood, M. D., Kroll, J. H., Flagan, R. C., Seinfeld, J. H., Lee, A., and Goldstein, A. H.: Hygroscopicity of secondary organic aerosols formed by oxidation of cycloalkenes, monoterpenes, sesquiterpenes, and related compounds, Atmos. Chem. Phys., 6, 23672388, doi:10.5194/acp-6-2367-2006, 2006.

Virkkula, A., Van Dingenen, R., Raes, F., and Hjorth, J.: Hygroscopic properties of aerosol formed by oxidation of limonene, $\alpha$-pinene, and $\beta$-pinene, J. Geophys. Res., 104, 3569-3579, doi:10.1029/1998jd100017, 1999.

Wang, L., Khalizov, A. F., Zheng, J., Xu, W., Ma, Y., Lal, V., and Zhang, R.: Atmospheric nanoparticles formed from heterogeneous reactions of organics, Nature Geosci., 3, 238-242, 2010.

Wang, M. and Penner, J. E.: Aerosol indirect forcing in a global model with particle nucleation, Atmos. Chem. Phys., 9, 239-260, doi:10.5194/acp-9-239-2009, 2009.

Weber, R. J., Marti, J. J., McMurry, P. H., Eisele, F. L., Tanner, D. J., and Jefferson, A.: Measurements of new particle formation and ultrafine particle growth rates at a clean continental site, J. Geophys. Res.-Atmos., 102, 4375-4385, doi:10.1029/96JD03656, 1997.

Westervelt, D. M., Pierce, J. R., and Adams, P. J.: Analysis of feedbacks between nucleation rate, survival probability and cloud condensation nuclei formation, Atmos. Chem. Phys., 14, 5577 5597, doi:10.5194/acp-14-5577-2014, 2014.

Wex, H., Petters, M. D., Carrico, C. M., Hallbauer, E., Massling, A., McMeeking, G. R., Poulain, L., Wu, Z., Kreidenweis, S. M., and Stratmann, F.: Towards closing the gap between hygroscopic growth and activation for secondary organic aerosol: Part 1 -Evidence from measurements, Atmos. Chem. Phys., 9, 3987 3997, doi:10.5194/acp-9-3987-2009, 2009.

Wiedensohler, A., Cheng, Y. F., Nowak, A., Wehner, B., Achtert, P., Berghof, M., Birmili, W., Wu, Z. J., Hu, M., Zhu, T., Takegawa, N., Kita, K., Kondo, Y., Lou, S. R., Hofzumahaus, A., Holland, F., Wahner, A., Gunthe, S. S., Rose, D., Su, H., and Pöschl, U.: Rapid aerosol particle growth and increase of cloud condensation nucleus activity by secondary aerosol formation and condensation: A case study for regional air pollution in northeastern China, J. Geophys. Res., 114, D00G08, doi:10.1029/2008jd010884, 2009.

Wiedensohler, A., Birmili, W., Nowak, A., Sonntag, A., Weinhold, K., Merkel, M., Wehner, B., Tuch, T., Pfeifer, S., Fiebig, M., Fjäraa, A. M., Asmi, E., Sellegri, K., Depuy, R., Venzac, H., Vil- 
lani, P., Laj, P., Aalto, P., Ogren, J. A., Swietlicki, E., Williams, P., Roldin, P., Quincey, P., Hüglin, C., Fierz-Schmidhauser, R., Gysel, M., Weingartner, E., Riccobono, F., Santos, S., Grüning, C., Faloon, K., Beddows, D., Harrison, R., Monahan, C., Jennings, S. G., O’Dowd, C. D., Marinoni, A., Horn, H.-G., Keck, L., Jiang, J., Scheckman, J., McMurry, P. H., Deng, Z., Zhao, C. S., Moerman, M., Henzing, B., de Leeuw, G., Löschau, G., and Bastian, S.: Mobility particle size spectrometers: harmonization of technical standards and data structure to facilitate high quality long-term observations of atmospheric particle number size distributions, Atmos. Meas. Tech., 5, 657-685, doi:10.5194/amt5-657-2012, 2012.

Wu, Z. J., Nowak, A., Poulain, L., Herrmann, H., and Wiedensohler, A.: Hygroscopic behavior of atmospherically relevant water-soluble carboxylic salts and their influence on the water uptake of ammonium sulfate, Atmos. Chem. Phys., 11, 1261712626, doi:10.5194/acp-11-12617-2011, 2011.

Wu, Z. J., Poulain, L., Henning, S., Dieckmann, K., Birmili, W., Merkel, M., van Pinxteren, D., Spindler, G., Müller, K., Stratmann, F., Herrmann, H., and Wiedensohler, A.: Relating particle hygroscopicity and $\mathrm{CCN}$ activity to chemical composition during the HCCT-2010 field campaign, Atmos. Chem. Phys., 13, 79837996, doi:10.5194/acp-13-7983-2013, 2013.

Yue, D. L., Hu, M., Zhang, R. Y., Wang, Z. B., Zheng, J., Wu, Z. J., Wiedensohler, A., He, L. Y., Huang, X. F., and Zhu, T.: The roles of sulfuric acid in new particle formation and growth in the mega-city of Beijing, Atmos. Chem. Phys., 10, 4953-4960, doi:10.5194/acp-10-4953-2010, 2010.
Yue, D. L., Hu, M., Zhang, R. Y., Wu, Z. J., Su, H., Wang, Z. B., Peng, J. F., He, L. Y., Huang, X. F., Gong, Y. G., and Wiedensohler, A.: Potential contribution of new particle formation to cloud condensation nuclei in Beijing, Atmos. Environ., 45, 6070-6077, doi:10.1016/j.atmosenv.2011.07.037, 2011.

Zdanovskii, B.: Novyi Metod Rascheta Rastvorimostei Elektrolitov v Mnogokomponentnykh Sistema, Zh. Fiz. Khim+, 22, 14781485, 1486-1495, 1948.

Zhang, Q., Stanier, C. O., Canagaratna, M. R., Jayne, J. T., Worsnop, D. R., Pandis, S. N., and Jimenez, J. L.: Insights into the Chemistry of New Particle Formation and Growth Events in Pittsburgh Based on Aerosol Mass Spectrometry, Environ. Sci. Technol., 38, 4797-4809, doi:10.1021/es035417u, 2004.

Zhang, R., Suh, I., Zhao, J., Zhang, D., Fortner, E. C., Tie, X., Molina, L. T., and Molina, M. J.: Atmospheric New Particle Formation Enhanced by Organic Acids, Science, 304, 1487-1490, doi:10.1126/science.1095139, 2004.

Zhu, Y., Hinds, W. C., Kim, S., and Sioutas, C.: Concentration and Size Distribution of Ultrafine Particles Near a Major Highway, J. Air Waste Manage., 52, 1032-1042, doi:10.1080/10473289.2002.10470842, 2002. 